\title{
Impacts of the Pandemic on Tourism Education from a Distance Education Perspective
}

\author{
Merve IŞKIN ${ }^{1}$, Ümit ŞENGEL ${ }^{2}$, Koray GENÇ ${ }^{3}$ \& İsmail UZUT ${ }^{4}$
}

\begin{abstract}
This study aimed to examine the distance education model in Turkey from the perspective of tourism education, which heavily includes applied courses, and to test its functionality in this way. Qualitative research methods were used in the study. The interview method was used to collect data. The obtained data were subjected to content analysis using the MAXQDA software. In addition, SWOT analysis of the distance education model in Turkey has been made using the obtained data. According to our findings, the strongest aspect of the distance education model is that it makes education sustainable. Moreover, it is emphasized that the model includes many opportunities to provide the necessary information and infrastructure for similar crises in the future. Besides these positive aspects, we also identified some negative consequences of the distance education model, including threats such as reducing students' sense of responsibility and weaknesses such as the inability to carry out the applied courses in the field of tourism.
\end{abstract}

Key Words: Distance Education, Tourism Education, COVID-19, SWOT Analysis

\section{Uzaktan Eğitim Perspektifinden Pandeminin Turizm Eğitimine Etkileri}

$\ddot{\mathrm{O} z}$

Bu çalışma, Türkiye'deki uzaktan eğitim modelini, ağırlıklı olarak uygulamalı dersler içeren turizm eğitimi açısından incelemeyi ve bu şekilde modelin işlevselliğini test etmeyi amaçlamaktadır. Araştırmada nitel araştırma yöntemleri kullanılmıştır. Veri toplamak için mülakat yöntemi kullanılmışır. Elde edilen veriler MAXQDA yazılımı kullanılarak içerik analizine tabi tutulmuştur. Ayrıca elde edilen veriler kullanılarak COVID-19 döneminde uygulanana Türkiye'deki uzaktan eğitim modelinin SWOT analizi yapılmıştır. Bu kapsamda, uzaktan eğitim modelinin en güçlü yanı, eğitimi sürdürülebilir kılmasıdır. Ayrıca modelin ileride yaşanabilecek benzer krizler için gerekli bilgi ve altyapıyı sağlamaya yönelik pek çok firsat içerdiği vurgulanmaktadır. Bu olumlu yönlerinin yanı sıra, öğrencilerde sorumluluk duygusunun azaltılması gibi tehditler ve turizm alanında uygulamalı derslerin gerçekleştirilememesi gibi zayıflıklar da dahil olmak üzere uzaktan eğitim modelinin bazı olumsuz sonuçları da belirlenmiştir.

Anahtar Kelimeler: Uzaktan Eğitim, Turizm Eğitimi, COVID-19, SWOT Analizi

\section{Atıf İçin / Please Cite As:}

Işkın, M., Şengel, Ü., Genç, K., \& Uzut, İ. (2022). Impacts of the pandemic on tourism education from a distance education perspective. Manas Sosyal Arasttrmalar Dergisi, 11(1), 98-112.

Geliş Tarihi / Received Date: 28.05.2021

Kabul Tarihi / Accepted Date: 5.10.2021

\footnotetext{
${ }^{1}$ Dr. Öğr. Üyesi, Ordu University, Vocational School of Social Sciences, Ordu, Turkey, merveiskin25@gmail.com

(i) ORCID: 0000-0002-4748-0422

2 Dr. Öğr. Üyesi, Sakarya University of Applied Sciences, Sakarya, Turkey, umitsengel@gmail.com

(iD ORCID: 0000-0003-1284-836X

3 Öğr. Gör. Dr. Mudurnu Süreyya Astarcı Vocational School, Bolu Abant İzzet Baysal University, Bolu, Turkey,

koray.genc@yahoo.com

(iD) ORCID: 0000-0001-5477-4683

${ }^{4}$ Dr. Öğr. Üyesi, Vocational School, Maltepe University, Istanbul, Turkey, ismailuzut@gmail.com

(iD ORCID: 0000-0001-6227-7249
} 


\section{Introduction}

The coronavirus (COVID-19 or 2019-nCoV), first revealed in Wuhan, China (Corman et al., 2020, p. 23; Gralinski \& Menachery, 2020, p. 1-2) in December 2019, has spread around the world and became a global health problem (Munster, et al., 2020, p. 692; Chang et al., 2020, p. 1092; Wang et al., 2020, p. 470; Menachery et al., 2020, p. 1-2). There have been various assumptions on the emergence of COVID-19. The most emphasis was put on assumptions on the consumption of animals served as fish in the city of Wuhan (Wang et al., 2020, p. 472; Holshue et al., 2020, p. 930; Perlman, 2020, p. 962), such as bats (Chu et al., 2020, p. 949) and pangolins (Lam et al., 2020; Wong et al., 2020). Belonging to the B generation of the beta coronavirus family, COVID 19 (Wang et al., 2020, p. 473) is associated with coronaviruses such as SARS and MERS, which also appeared in recent years. However, over time, it has been mutated and became different from the others (Backer et al., 2020, p. 1).

Even though COVID-19 has a lower rate of mortality compared to the other coronaviruses, its very rapid spread makes this type of virus more dangerous (Chu et al., 2020, p. 450). The virus was found to have an incubation period of 6.4 days and a reproduction number of 2.24-3.58, and it is transmitted to humans through droplets or by physical contact. The main symptoms are high fever and dry cough (Huang et al., 2020, p. 498), but it also presents with symptoms such as fatigue, headache, and sputum (Paules et al., 2020, p. 708). The COVID-19 virus specifically damages the lungs and causes death in humans by respiratory problems and organs failure (Chen et al., 2020, p. 507). According to data from the World Health Organization (WHO), 2,078,605 people worldwide have been infected, and 139,515 people have died due to COVID-19 since the first time the virus was detected and until April 17th, 2020 (WHO, 2020). Because the virus is easily transmitted to humans, it has spread increasingly fast, and this led to many changes in global balances. To reduce the spread of the virus, many countries including China, Italy, Greece, Japan, and Turkey have imposed curfews, partially or across the country. The efforts to reduce the spread have affected many areas of life and have brought life to a standstill. The main area that has been affected by COVID-19 is education.

Many countries have paused education, some even bringing it to a halt (Crawford et al., 2020, p. 2). In Turkey, various measures were taken regarding education after the first case of COVID-19 was seen in the country. First, short-term measures were taken within this scope by the Presidency of Turkey . Then, the Council of Higher Education, which all the universities of Turkey are affiliated with, decided on 18.03.2020 to continue education at universities through distance education in the Spring term of the academic year of 2019-2020 (YÖK, 2020). However, there have been some concerns about the applicability of this process in certain institutions, faculties, or departments due to their qualifications. In light of this information, we aimed to reveal the functionality of the distance education model in tourism departments, which mainly consists of applied courses.

\section{Literature Review and Research Question}

Depending on the type of crisis that occurs in a country, the education system may remain unaffected. However, in crises such as natural disasters, wars, or epidemics, education systems are affected, and students' right to education is compromised. The world has witnessed the COVID-19 epidemic affect the whole world and change lives in many ways. To prevent the spread of the virus, many countries have decided to pause education processes. This forced educators and administrators to develop new solutions and strategies to maintain educational activities at all stages. In this regard, many institutions of higher education in various countries have switched to the distance education model to ensure continuity in education. Compared to formal education, distance education has a more flexible structure, imposes more responsibilities on students, and offers different options for providing learning (Zayapragassarazan, 2020, p. 3).

In this context, it is safe to say that the competition between distance and formal education models has gained a new perspective due to the COVID-19 pandemic. The distance education model conducted by experts (Kumar et al., 2019, p. 1958) might have disadvantages such as a weak communication process, but it should be noted that it has some important advantages as well. Some of these advantages are that lessons can be recorded in a way that they can be viewed afterwards, these recordings can be paused and replayed, subtitles can be used in case the teacher talks too quickly (Semenikhina et al., 2019, p. 899), students can easily have an access to the course materials, transportation costs, and the risk of infection spread is minimized (Sadeghi, 2019, p. 85). 
There are some academic studies in different fields on the functionality of the distance education model. These studies are focused mostly on fields where applied courses are predominant, particularly medical education. Lin et al. (2020, p. 2) conducted an empirical study on fourth-grade medical students taking " $5+3$ " model courses on internal medicine. As a result, they revealed that combining team-based learning (TBL) and online interaction, 5G network-based medical education was the most appropriate option for medical students during the COVID-19 pandemic. Chick et al. (2020, p. 730) emphasize that in medical education, a model can be used where the teacher enriches the subject through technological tools such as videos. This method includes various innovative solutions such as teleconferencing, telemedicine clinics, procedure simulations, and facilitated the use of surgical videos. This type of experience may not be a perfect substitute for applied learning through direct patient care, but it is an alternative that can reduce the loss of learning in applied courses in this compulsory process. Other similar innovative solutions based on technology have also been used before the COVID-19 pandemic. For example, surgical videos have been used for a long time to save time in medical education. However, these videos should be of high quality (Jayakumar et al., 2015, p. 1149; Deal \& Alseidi, 2017, p. 727; Rodriguez et al., 2018, p. 1726; Augestad et al., 2019, p. 233).

The education process might seem to focus on an online education model due to the COVID-19 pandemic, but many countries are caught off-guard against distance education due to the sudden emergence of this epidemic. We can say that a significant part of the work in distance education depends on organizational commitment and strong communication (Zhaohui, 2020). However, despite this optimistic picture, it should be kept in mind that there are institutions with insufficient distance education resources and socially disadvantaged students with limited access to technology and the internet, which affect their institutional response and capability to access an online environment (Zhong, 2020). Hence, this compulsory process will be a test of whether academics and higher education institutions are ready for digital learning in the coming years (Houlden \& Veletsianos, 2020).

Like in many other countries, the higher education system in Georgia has been affected by the COVID-19 pandemic. Education was paused in the country on March 2nd, 2020 to reduce the spread of the disease. However, educators have sought an alternative strategy to ensure the functioning of society and to not postpone education until the summer and autumn. In this regard, Georgia has tested and implemented applications such as Gmail, Classroom, Calendar, Forms, Jamboard, Drawings, Drive, and Hangouts for distance education. However, various standards are required to be provided in certain subjects to carry out distance education smoothly. These are (Basilaia et al., 2020, p. 101):

- The infrastructure must be able to connect with at least 50 students at the same time via interactive conference.

- It must be able to enable mutual interaction in online courses to make the teaching process more organic and realistic.

- The videos must be recorded and uploaded to the system for students who do not have access to a fast internet connection.

- The online courses should be accessible not only on computers but also on mobile applications.

- The infrastructure must enable students to replay the lessons they missed.

- The system must allow students to complete and deliver their assignments, quizzes, and tests online.

Struggling with the COVID-19 pandemic, Malaysians have started to stay at home with the Movement Control Order (MCO). In this process, the stable and easily accessible internet has been the backbone of the country. The distance education model has been the key tester of this backbone. As the Malaysian government directs teachers, parents, and students to online classrooms, it tests both their adaption to distance education and the success of reliable internet connections. In addition, the department of educational resources and technology (Bahagian Sumber dan Teknologi Pendidikan BSTP) of the Ministry of National Education of Malaysia published online resources approved by Google's digital learning website for the stakeholders (teachers, students, and parents) in the education sector.

One of the countries that have most felt the effects of the COVID-19 pandemic on education has been China, the country where the first case was revealed. As the fast spread of the virus was detected, universities in China quickly moved their curricula to the online environment, paying great attention to the technology and websites available in China. As the virus kept spreading, all countries turned to 
mechanisms of their operations to solve the problems in higher education (Crawford et al., 2020, p. 9). In this context, the Chinese government launched the large-scale online education application, "School's Out, but Class's On". Thus, education activities have proceeded in a more controlled way in China, the starting point of the epidemic (Zhou et al., 2020, p. 503).

Education has also been one of the primary areas affected by the pandemic in the United States of America (USA). As in other countries, the USA continues to work on online education practices in schools across the country. In this context, students need to communicate effectively through existing online schools and online content providers. In addition, there is an expectation in the USA for political decision-makers to offer various incentives to schools for better flexibility using available resources. Through these incentives, schools can direct their expenditures such as taxes to other areas as needed. Finally, the Department of Education has published a guide to removing the barriers to schools that are trying to provide online course materials. On the other hand, the epidemic provides an opportunity to see how quickly and how extensively educators in public and private educational institutions in the USA can expand virtual education, suggesting that society will change the way they think about education in the future (Butcher, 2020, p. 2-3).

Almost all the countries in the world with detected cases have switched to the distance education model. It is a fact that the success in this process will be determined by the socio-economic structures of these countries. In this context, it is useful to examine the example of Portugal, one of the countries that have had difficulties in the transition to distance education. The country has shown great reflex to overcome all the negative effects of the pandemic on education. However, as digital sufficiency, personal computers, and internet access are not commonly available for the entire population of Portugal, some difficulties have been emphasized. These difficulties have raised questions such as Is Portugal ready to halt education as a whole? Do all students with compulsory education own a computer with internet access? Are the parents ready to support and encourage their children to learn? Has the necessary investment been made to provide sufficient and secure e-learning platforms and tools to schools? Is there a correct teacher training plan in recent years that allows them to teach through e-learning, not only in terms of technological sufficiency but also in terms of education strategies? Can parents stay at home to support and help their children without having their payrolls and jobs suffer? All these questions and the answers to them are of great importance and have raised concerns about the functionality of distance education, which Portugal has mandatorily switched to (Jose Sa \& Serpa, 2020, p. 527). The questions of this research are in parallel with the questions in the current study. The research questions we developed in this context are as follows:

- What are the strengths and weaknesses of the distance education model in higher education in Turkey for tourism education, which is heavily based on applied courses?

- What are the opportunities and threats of the distance education model in higher education in Turkey for tourism education, which is heavily based on applied courses?

\section{Method}

The qualitative research method was used. The data were collected by interviews. An unstructured process was conducted, and a vast majority of the interviews were carried through teleconference. The driving reason for the research, the COVID-19 epidemic, and the imposed travel restrictions have not allowed the interviews to be conducted physically. Physical interviews could be done only with the academicians in the same institution as the researchers.

\section{The Aim and Importance of the Study}

This study aimed to evaluate the feasibility and, more importantly, the efficiency of distance education, which the higher education institutions in Turkey have made the transition to in a fast and compulsory way due to the COVID-19 epidemic, on tourism and related departments (travel, culinary arts, etc.). For this purpose, we asked the opinions of the faculty members of the tourism department as they were expected to evaluate the current situation within the scope of their departments and institutions. The lack of any field research on distance education in the field of tourism makes this study important in this sense.

While the current situation is a temporary process, the idea that distance education will become more widespread in its usual course than an alternative method used in times of crisis requires the preparation 
of departments that are based on applied courses, such as tourism. The current situation can be considered as some kind of drill for tourism education through distance education practices, and it provides an important opportunity to test its feasibility and efficiency. Research data are collected from academicians, the key participants of this drill. And these data are considered to be valuable for the future by offering an important experience backup on the subject.

\section{Sampling and Data Collection}

While the sample size is no longer a topic of debate in quantitative research thanks to formulations, it remains to be discussed for qualitative research. Here, the term saturation (Yağar \& Dökme, 2018: 4) stands out for the sampling of qualitative research, which indicates the necessity to continue sampling until no different data is obtained. Saturation was also considered in this study, and the research sample was limited to 39 people.

Table 1. Participant Information

\begin{tabular}{|c|c|c|c|c|c|c|c|c|c|c|c|}
\hline 1 & 2 & 3 & 4 & 5 & 6 & 1 & 2 & 3 & 4 & 5 & 6 \\
\hline G1 & Public & 6 & Lecturer & 34 & Male & G21 & Public & 5 & Assist. Prof. Dr. & 33 & Female \\
\hline G2 & Public & 3 & Assis. Prof. Dr. & 37 & Female & G22 & Public & 6 & Dr. & 34 & Female \\
\hline G3 & Public & 2 & Lecturer & 39 & Female & G23 & Public & 18 & Assist. Prof. Dr. & 42 & Male \\
\hline G4 & Public & 8 & Lecturer & 43 & Female & G24 & Public & 1 & Dr. & 26 & Male \\
\hline G5 & Public & 2 & Lecturer & 31 & Male & G25 & Public & 5 & Lecturer & 32 & Male \\
\hline G6 & Public & 16 & Dr. & 42 & Female & G26 & Foundation & 3 & Dr. & 30 & Female \\
\hline G7 & Public & 23 & Assoc. Prof. Dr. & 49 & Male & G27 & Foundation & 1 & Dr. & 30 & Male \\
\hline G8 & Public & 6 & Dr. & 30 & Female & G28 & Public & 2 & Dr. & 27 & Male \\
\hline G9 & Public & 8 & Dr. & 40 & Female & G29 & Public & 8 & Dr. & 38 & Female \\
\hline G10 & Public & 3 & Lecturer & 33 & Male & G30 & Public & 7 & Lecturer & 33 & Male \\
\hline G11 & Public & 8 & Dr. & 33 & Female & G31 & Foundation & 2 & Lecturer & 32 & Female \\
\hline G12 & Public & 35 & Assoc. Prof. Dr. & 61 & Female & G32 & Foundation & 7 & Lecturer & 36 & Male \\
\hline G13 & Foundation & 18 & Lecturer & 44 & Male & G33 & Public & 20 & Lecturer & 49 & Male \\
\hline G14 & Foundation & 15 & Assoc. Prof. Dr. & 38 & Female & G32 & Public & 8 & Prof. Dr. & 31 & Male \\
\hline G15 & Foundation & 5 & Assist. Prof. Dr. & 35 & Female & G35 & Public & 12 & Dr. & 35 & Male \\
\hline G16 & Foundation & 5 & Lecturer & 35 & Female & G36 & Public & 7 & Assist. Prof. Dr. & 34 & Male \\
\hline G17 & Public & 8 & Assist. Prof. Dr. & 34 & Female & G37 & Public & 3 & Assist. Prof. Dr. & 31 & Male \\
\hline G18 & Public & 2 & Lecturer & 34 & Female & G38 & Public & 8 & Assist. Prof. Dr. & 33 & Female \\
\hline G19 & Public & 3 & Assist. Prof. Dr. & 36 & Male & G39 & Public & 20 & Lecturer & 50 & Male \\
\hline G20 & Public & 2 & Assist. Prof. Dr. & 48 & Male & & & & & & \\
\hline
\end{tabular}

Also, the maximum diversity method was used in sample creation. This method aims to reveal the common denominators and the different dimensions between variable situations (Baltac1, 2018). Accordingly, we ensured that the interviewed faculty members were distributed to as many different titles and universities as possible. Information about the participants is given in Table 1.

\section{Data Analysis}

Opinions on the subject of the research were transcribed and put together, and a total of 52 pages of raw data were obtained. The raw data were subjected to content analysis using a computer. The MAXQDA software was used in the analysis. MAXQDA is an analysis software used to clarify ideas and to understand the hypothetical relationships between categories and characteristics (Azzopardi \& Nash, 2016, p. 254). Thematic coding was done for content analysis on MAXQDA (Kuckartz \& Radiker, 2019, p. 10). The themes were identified as strengths, weaknesses, opportunities, and threats. The codes under the themes were student, staff (technical and academic), education (theoretical and practical), infrastructure (internet access, information, etc.), and university (organizational structure, organizational communication). The answers of the participants were evaluated separately by 4 researchers and a SWOT analysis was made regarding to the distance education model. These four SWOT analyses were then evaluated together. The factors that four researchers touched upon were reflected in the SWOT table of the research and this table is given in the discussion part.

\section{Validity and Reliability}

"Diversification" is an important strategy for validity in studies conducted with qualitative research methods. The diversification strategy aims to increase the credibility of the findings. In this research, we applied three different diversification strategies reported by Patton (2002, p. 345). 
1. Data Diversification: Data were collected from faculty members at different universities and different titles. The fact that the researchers were experiencing the same process as the faculty members included in the sample allowed their individual experiences to be evaluated as data diversification.

2. Researcher Diversification: Four researchers were included in data collection and data analysis. The researchers conducted their analyses before the content analysis was completed. Then, the debate process was carried out to meet at a common ground for themes and codes.

3. Methodological Diversification: Because of the current process (travel restrictions due to the Covid-19 pandemic) and because the individuals forming the sample were scattered to different cities, we found it appropriate to use different methods, especially in data collection. We used different methods such as physical interviews, teleconferences, e-mails, and e-questionnaires to collect the opinions of the sample, while also sticking to the interview method. In addition, we aimed to diversify the sample in terms of institutions and titles using the snowball sampling method.

One of the main problems of qualitative research is reliability in case if proper care is not taken. The reliability provided by mathematical formulations in quantitative research is based on the ethical values and practices of researchers in qualitative research. We took care to consider ethical values in this research, and all interviews were recorded and written down. All the researchers conducted their analyses on the raw data to ensure consistency. As a result of separate content analyses, themes that were not consistent were excluded from the research.

\section{Findings}

The data obtained within the study were analyzed and reported separately. A word analysis was done for the data obtained from the interviews, and the most repeated words are shown with their frequencies in Table 2 and the word cloud in Figure 1. The words repeated more than 20 times were taken to the word cloud. However, the evaluations are listed according to how the words were mentioned. Because the frequency of mention reveals the importance given to the word by the participants in the information they provided on the subject. As expected, the top three words were education $(100 \%)$, student $(87.5 \%)$, and lesson $(62.5 \%)$. It is observed that these words were followed by those covering the issues related to distance education. Some of these were technical (50\%), internet (50\%), and infrastructure $(37.5 \%)$.

Table 2. The Most Repeated Words

\begin{tabular}{|c|c|c|c|}
\hline Number & Word & Frequency & Document (\%) \\
\hline 1 & education & 777 & 100,00 \\
\hline 2 & student & 303 & 87,50 \\
\hline 3 & lesson & 247 & 62,50 \\
\hline 4 & Internet & 36 & 50,00 \\
\hline 5 & technical & 20 & 50,00 \\
\hline 6 & time & 61 & 50,00 \\
\hline 7 & infrastructure & 39 & 37,50 \\
\hline 8 & deficiency & 31 & 37,50 \\
\hline 9 & opportunity & 27 & 37,50 \\
\hline 10 & teaching & 44 & 37,50 \\
\hline 11 & Turkey & 20 & 37,50 \\
\hline 12 & university & 21 & 37,50 \\
\hline 13 & strong & 41 & 25,00 \\
\hline 14 & institution & 20 & 25,00 \\
\hline 15 & formal & 42 & 25,00 \\
\hline 16 & time & 20 & 25,00 \\
\hline 17 & application & 24 & 25,00 \\
\hline 18 & academician & 59 & 12,50 \\
\hline 19 & asynchronous & 19 & 12,50 \\
\hline 20 & alive & 39 & 12,50 \\
\hline 21 & continuation & 33 & 12,50 \\
\hline 22 & teacher & 21 & 12,50 \\
\hline 23 & record & 21 & 12,50 \\
\hline 24 & online & 52 & 12,50 \\
\hline 25 & exam & 23 & 12,50 \\
\hline 26 & system & 44 & 12,50 \\
\hline 27 & face-to-face & 35 & 12,50 \\
\hline
\end{tabular}


Moreover, it was seen that the expectations of students were repeated frequently in the interviews, as in opportunity (37.5\%), exam (12.5), and record (12.5\%). Here, the word "opportunity" should be considered separately. Because, although the study carried out the SWOT analysis of distance education applied after the epidemic, an opportunity was the most mentioned element of the four factors examined. This shows that academics perceive this essential education model as a process that can be turned into an opportunity for universities. The word cloud for these word frequencies is shown in Figure 1.

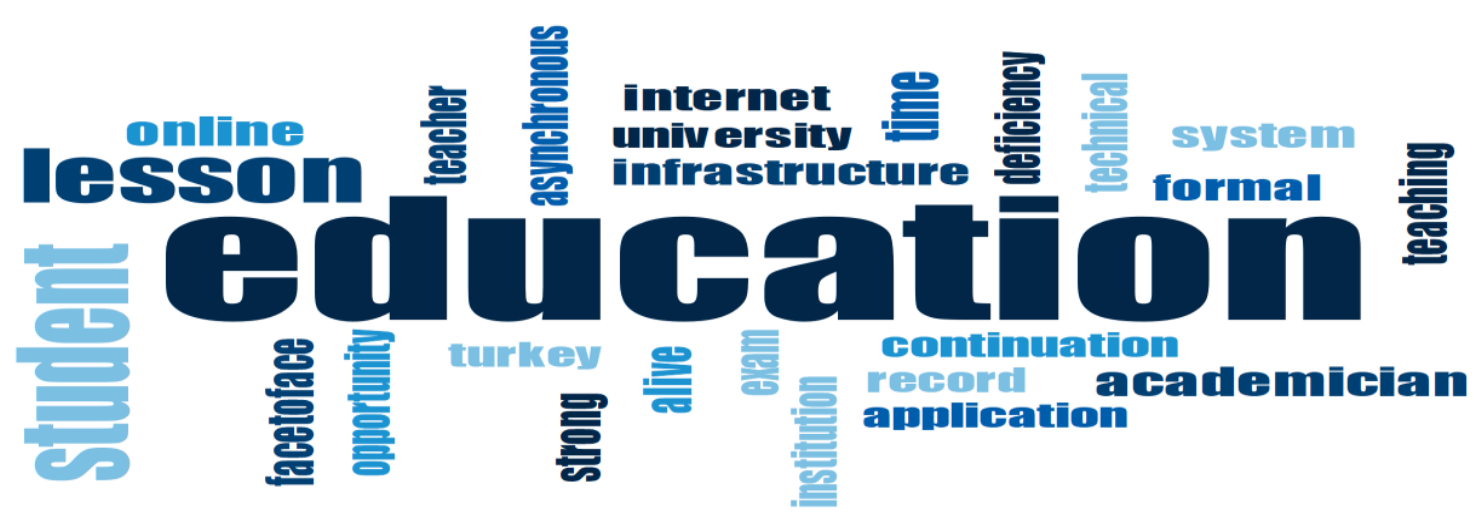

Figure 1. Word Cloud for Research Results

Figure 2 shows the relationship scanners for the evaluation of distance education in higher education in Turkey after COVID-19. The strengths, weaknesses, opportunities, and threats of distance education are given separately for tourism-related departments. As seen in Figure 2, education was the most emphasized by the participants in the context of strengths. Besides education, university and infrastructure were some of the prominent codes regarding strengths. The picture is similar in terms of opportunities. The participants most mentioned the concepts of education, university, and infrastructure on the opportunities of the distant education model. The fact that the elements of the strengths and opportunities in SWOT analysis were positive made these results similar. In the determination of these findings, concepts such as communication, organization, internet, access, and information had an important share. There was also an interaction between the sub-codes of strengths and opportunities.

\begin{tabular}{|c|c|c|c|c|c|c|c|c|}
\hline Code System & Strengths & Infrastructure & \multicolumn{2}{|c|}{ University-Institution } & Education (Theoric-Applied) & Student & \multicolumn{2}{|c|}{ Staff (Technica-Acadenic) } \\
\hline \multicolumn{9}{|l|}{$\vee$ Strengths } \\
\hline \multicolumn{9}{|l|}{ @infrastructure } \\
\hline \multicolumn{9}{|l|}{ University-Institution } \\
\hline \multicolumn{9}{|l|}{ (Education (Theoric-Applied) } \\
\hline \multicolumn{9}{|l|}{ Student } \\
\hline \multicolumn{9}{|l|}{ Staff (Technical-Academic) } \\
\hline Code Sytem & Weaknesses & Staff (Techni & -Academic) & Student & Education (Theoric-Applied) & Universit & -Institution & Infrastructure \\
\hline \multicolumn{9}{|l|}{$\checkmark$ Weaknesses } \\
\hline \multicolumn{9}{|l|}{ @Staff (Technical-Academic) } \\
\hline \multicolumn{9}{|l|}{$\bigodot_{0}$ Student } \\
\hline \multicolumn{9}{|l|}{$\bigodot_{0}$ Education (Theoric-Applied) } \\
\hline \multicolumn{9}{|l|}{ Q. University-Institution } \\
\hline$\varrho_{0}$ Infrastructure & $\mathbf{\square}$ & & & . & . & & । & \\
\hline
\end{tabular}




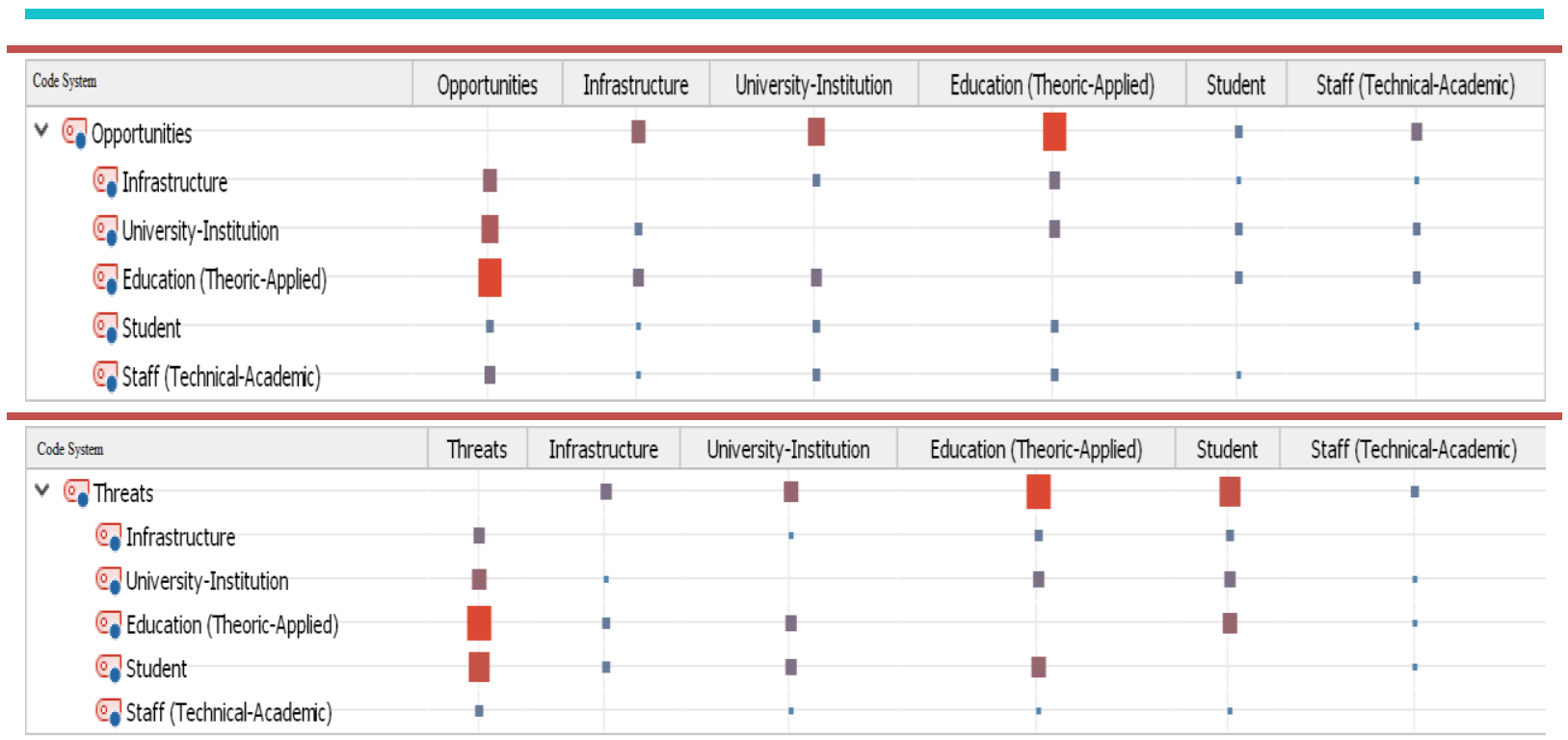

Figure 2. Relationship Scanners for Themes and Codes

Examining the opinions of the participants regarding the system, education and infrastructure stood out in terms of weaknesses. Because of the sudden emergence of this epidemic, some universities had to start this process without the necessary infrastructure or a functional one. This was reflected in the opinions of the participants. It was observed that weaknesses were concentrated on the opinions of students. This was even more evident in threats. Education and students were the reaserch themes that the participants were most focused on in threats. Figure 2 shows that these two themes were related to each other.

The themes that make up the SWOT analysis regarding distance education and the relations between the sub-codes of these themes are given in Figure 3 along with the map of relation codes. Here, a separate code map is given for each element of the SWOT analysis. The thickness of the lines between the concepts shows the strength of the relationships between them. In addition, the transitions between the codes outside the main theme reflect the relationships between these codes.

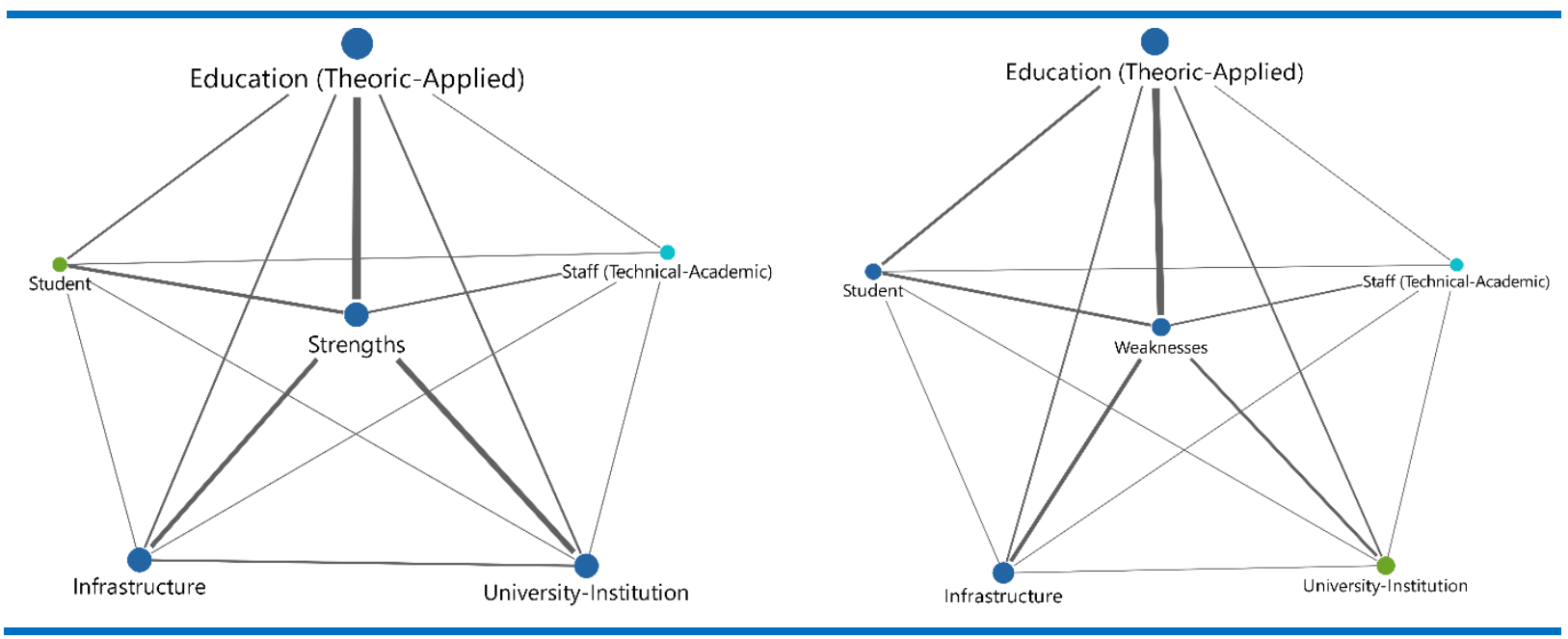




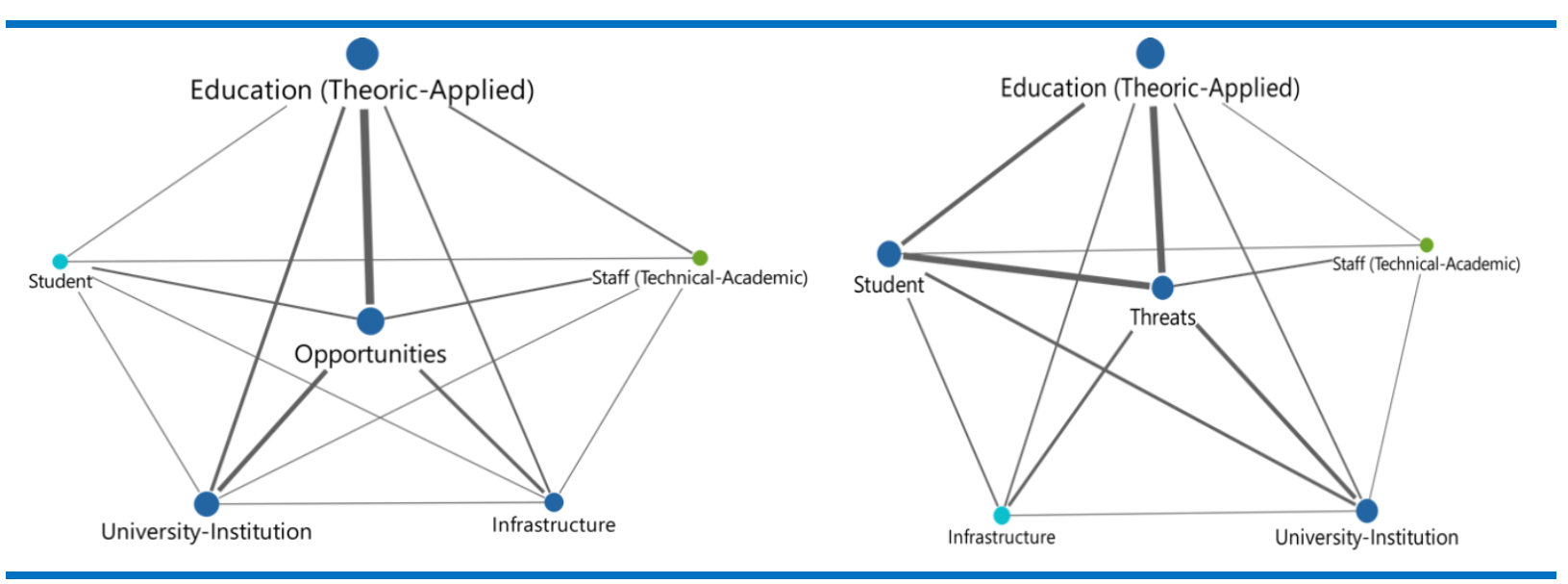

Figure 3. Code Maps for Themes

Figure 3 shows strong relations between all four elements of SWOT analysis and education. Other factors about strengths were infrastructure and university. In opportunities, universities or institutions were prominent in addition to education. This may suggest an opportunity for universities to make the transition to distance education. In weaknesses, students and infrastructure were two prominent elements. The participants emphasized that there were some problems with the necessary infrastructure. In threats, the student was identified as a very important element. It was even more prominent than the theme of education. It was emphasized that students who cannot even adapt to formal education could pose a particular problem.

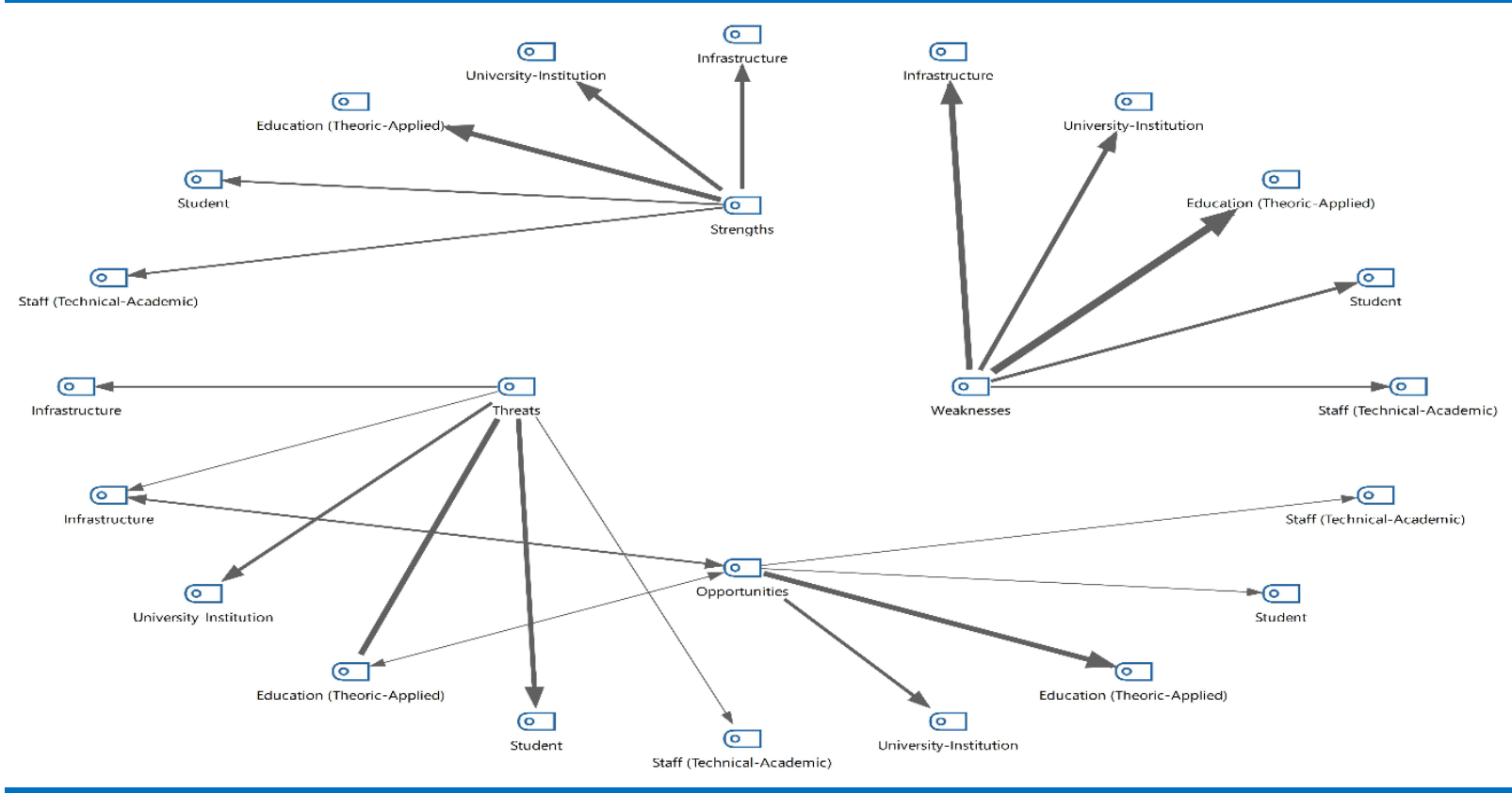

Figure 4. Relationship Scanners for Codes

Figure 4 shows the relationship scanners for codes. It is seen that none of the sub-codes of strengths and weaknesses was in relation with each other. However, in opportunities and threats, infrastructure and education codes were found to be in relation. These two elements were considered as both a threat and opportunity by most participants.

\section{Discussions and Conclusion}

A SWOT analysis was made for the distance education model using data obtained in the research, and the most prominent findings are reported in Table 3. While academicians in the field of tourism stated that the distance education model has some strengths and opportunities in the context of tourism education, they also stated that the model has more weaknesses and threats. Similar to this research, Jose 
Sa and Serpa (2020, p. 528) researched the strategies that reveal the obstacles and opportunities of the educational paradigm in Portugal following the changes after COVID-19.

The strongest aspect of this education model is that it ensures the sustainability of education in the crisis after the epidemic (Zhou et al., 2020, p. 512). In addition, the fact that generation $Z$ makes up the students in education, especially in the current education system, makes the model strong (Jones et al., 2007, p. 887; Turner, 2015, p. 110; Skinner et al., 2018, p. 98; Haddouche \& Salomone, 2018, p. 73-74). Because the youth of this generation have both curiosity and ability for technology. Other strengths of this model include the replayable video recordings of courses and accessible resources (Semenikhina et al., 2019, p. 901; Gong, 2020, p. 1).

It was emphasized that the model also brought some opportunities for the education system of Turkey. The key opportunity here is that the model provides the necessary infrastructure and information for similar crises in the future (Basilaia et al., 2020, p. 104). In a global environment where international relations have moved away from physical war and terrorism and towards biological war, such crises are likely to emerge again in the future. Because, since the millennium, a considerable number of pandemics have occurred, 3 of which being coronaviruses. In addition, technology and its use it is spreading to larger areas every day. Education is in the lead in these areas. In this context, we can say that this education model brings key opportunities in terms of providing the preliminary experience for online education (Mirzakhani et al., 2010, p. 34), which is expected to become widespread in the future. It also contains some opportunities in terms of providing a flexible working system and saving time, especially for academic staff (Chehayeb, 2015).

Table 2. Evaluations of Academicians for Distance Education (SWOT Analysis)

\begin{tabular}{ll}
\hline Strength; & Weaknesses; \\
- Sustainable education & - Internet access problems \\
- Technological abilities and curiosities of students & - Infrastructure deficiencies \\
- Lack of restrictions such as time and space & - Lack of applied courses \\
- Recording and replaying lessons & - Asynchronous applications that limit interactivity \\
- Easy resource sharing & - Failure to check attendance \\
- Auditable education & - Problems in measurement and evaluation \\
& - Lack of knowledge and experience on the subject \\
& - Students not taking distance education seriously \\
\hline Opportunities; & - Inability to check whether students are active in courses \\
- Providing the necessary infrastructure and & Threats; \\
information for similar crises in the future & - Negatively affecting the social relations of students in \\
- Preliminary experience for online education & tourism, which is a social phenomenon \\
expected to become widespread in the future & - Reducing the sense of responsibility of students \\
- Flexible working & - Risk of reducing quality in education \\
- Contribution to the brand value of universities & - Transition to distance education very quickly and \\
- Sustainable competitive advantage & without taking the necessary measures due to the \\
- Cost advantage and additional income & - epidemic \\
& - Information pollution \\
& - Risk of damaging or ending formal education \\
& - Distancing students from the discipline of schools and \\
& - Unethical behaviors \\
& courses
\end{tabular}

According to tourism academics, the distance education model has certain important weaknesses in terms of tourism education. First, this model prevents the implementation of applied courses, which are necessary for tourism education. Students could not even complete their internships. In addition, access problems due to the internet and the lack of infrastructure are some of these weaknesses. Institutions that provide formal education are particularly expected to have deficiencies in terms of infrastructure (Jose Sa \& Serpa, 2020, p. 529). There are two main problems regarding internet access. First, the overuse of the internet can slow down the connection, as all life is currently being lived online. Second, students who went to their hometowns in rural areas may have problems with internet access (Zhong, 2020; MCMC, 
2020; Gong, 2020, p. 3; Issa, 2020; Datahaus, 2020). Other weaknesses of the model are asynchronous applications that prevent interactivity and problems in measurement and evaluation. Guo and $\mathrm{Li}$ (2020, p. 548) stated that live lessons where students can be fully interactive and ask questions aloud would be more effective instead of asynchronous applications. Zhuo et al. (2018, p. 39) address the importance of interactive communication between teachers and students for successful education. Thus, asynchronous applications constitute an important weakness in this model. This shows similarity with the results of the study of Yao et al (2020, p. 522).

The biggest risk of this education model in terms of tourism education is in the context of social relations. Tourism is a social phenomenon where employees should have strong social relations. It is safe to say that this model negatively affects the social relationships of students. In addition, the inability to carry out applied courses in departments such as tourism gives this model the risk of reducing the quality of education in such departments. Also, the model may deepen inequality of opportunity between students, especially due to the social dynamics of universities and society in Turkey. $\operatorname{Li}(2019$, p. 146) states that it is not appropriate to apply similar education models or lessons for students with different learning needs and conditions. The model also carries the danger of unethical behaviors during its implementation.

COVID-19 has affected life in many ways. Most routine activities in social life have come to a halt. However, the form of implementation of educational activities has been changed, and education has been continued through the distance education model. Of course, this has great importance for the sustainability of education. However, there are inevitable concerns about the functionality of this practice in fields based on applied courses, such as tourism.

In this article, we carried out a SWOT analysis of the distance education model in higher education in Turkey in terms of tourism education. Strengths such as contributing to the sustainability of education, the ability of students to use technology, and their curiosity in this regard, making education more controllable and not being dependent on a time and place are frequently stated. Some of the weaknesses include the lack of infrastructure, not being suitable for applied courses, possible internet access problems, and asynchronous applications that are not suitable for interactive activities. It was also emphasized that this education model includes certain opportunities such as providing the necessary infrastructure and information for similar crises in the future, creating the first collective experience for online education, which is expected to become widespread in the future, enabling flexible working and contributing to the brand value of universities. Finally, it can be said to include certain threats such as negatively affecting the social relations of tourism students, reducing the sense of responsibility of students, risk of reducing the quality of education, and transition to the model very quickly and without taking the necessary measures due to the epidemic.

This research had several important limitations. The first and the biggest limitation was the ongoing epidemic. Due to the crisis, data could not be collected face-to-face. While this problem can be overcome with a semi-structured interview method, interviews were conducted in online environments (teleconference) due to curfew restrictions and the social distancing rule. Another limitation was that some of the academics did not want to give information about the distance education model applied in their institutions. Thus, since we could not reach a larger sample, the answers began to be repeated after a certain number of participants, and the data collection process was ended with 39 participants.

Considering the literature review and the limitations of this study, some suggestions can be made for future research. First, as determined in this research, we can say that distance education is not suitable for tourism education as it is heavily based on applied courses. So, the subject can be examined in the context of other fields based on applied courses. Further quantitative studies can be conducted to measure the perceptions, attitudes, and expectations on the subject. Studies comparing models in different countries and their success indicators can also contribute to the literature. In addition, it should be kept in mind that this education model was implemented very quickly and without taking the necessary measures. Thus, it contains certain dangers (Carey, 2020). So, the same subject can be repeated with more extensive participation using a semi-structured interview method.

\section{Ethical Declaration}

In the writing process of the study titled "Impacts of the Pandemic on Tourism Education from a Distance Education Perspective", there were followed the scientific, ethical, and citation rules; was not made any 
falsification on the collected data and this study was not sent to any other academic media for evaluation. Since the data set is used in this article, ethics committee approval is not required.

\section{References}

Augestad, K. M., Butt, K., Ignjatovic, D., Keller, D. S., \& Kiran, R. (2019). Video-based coaching in surgical education: a systematic review and meta-analysis. Surgical endoscopy, 239, 233-241.

Azzopardi, E., \& Nash, R. (2016). A framework for island destination competitiveness - perspectives from the island of Malta. Current Issues in Tourism, 19(3), 253-281.

Backer, J. A., Klinkenberg, D., \& Wallinga, J. (2020). Incubation period of 2019 novel coronavirus (2019-nCoV) infections among travelers from Wuhan, China, 20-28 January 2020. Euro Surveillance, 25(5), 2000062.

Baltacı, A. (2018). Nitel araştirmalarda örnekleme yöntemleri ve örnek hacmi sorunsalı üzerine kavramsal bir inceleme. Bitlis Eren Üniversitesi Sosyal Bilimler Enstitüsü Dergisi, 7(1), 231-274.

Basilaia, G., Dgebuadze, M., Kantaria, M., \& Chokhonelidze, G. (2020). Replacing the classic learning form at universities as an immediate response to the COVID-19 virus infection in Georgia. International Journal for Research in Applied Science \& Engineering Technology (IJRASET), 8(3), 101-108.

Butcher, J. (2020). Public-private virtual-school partnerships and federal flexibility for schools during COVID-19. Mercatus Center Research Paper Series, George Mason University Special Edition: Policy Brief (2020).

Cárdenas-García, P. J., Sánchez-Rivero, M., \& Pulido-Fernández, J. I. (2015). Does tourism growth influence economic development?. Journal of Travel Research, 54(2), 206-221.

Carey, K. (2020). Everybody ready for the big migration to online college? Actually, no. The New York Times, Retrieved March 13, 2020 from https://www.nytimes.com/2020/03/13/upshot/coronavirus-online-collegeclasses-unprepared.html

Chang, D., Lin, M., Wei, L., Xie, L., Zhu, G., Cruz, C. S. D., \& Sharma, L. (2020). Epidemiologic and clinical characteristics of novel coronavirus infections involving 13 patients outside Wuhan, China. Jama, 323(11), 10921093.

Chehayeb, A. (2015), New in classroom: Saving time while grading, Google Cloud official blog. Retrieved May 25, 2020 from https://cloud.googleblog.com/2015/12/new-in-Classroom-saving-time-while-grading.htm

Chen, N., Zhou, M., Dong, X., Qu, J., Gong, F., Han, Y., Qiu, Y., Wang, J., Liu, Y., Wei, Y., Xia, J., Yu, T., Zhang, X. \& Zhang, L. (2020). Epidemiological and clinical characteristics of 99 cases of 2019 novel coronavirus pneumonia in Wuhan, China: a descriptive study. The Lancet, 395(10223), 507-513.

Chick, R. C., Clifton, G. T., Peace, K. M., Propper, B. W., Hale, D. F., Alseidi, A. A., \& Vreeland, T. J. (2020). Using technology to maintain the education of residents during the COVID-19 pandemic. Journal of Surgical Education, (Article in Press).

Chu, D. K. W., Pan, Y., Cheng, S. M. S., Hui, K. P. Y., Krishnan, P., Liu, Y., Ng, D. Y. M., Wan, C. K. C., Yang, P., Wang, Q., Peiris, M. \& Poon, L. L. M. (2020). Molecular diagnosis of a novel coronavirus (2019-nCoV) causing an outbreak of pneumonia. Clinical chemistry, 66(4), 549-555.

Corman, V. M., Landt, O., Kaiser, M., Molenkamp, R., Meijer, A., Chu, D. K............., \& Drosten, C. (2020). Detection of 2019 novel coronavirus (2019-nCoV) by real-time RT-PCR. Euro Surveill, 25(3), 2000045.

Crawford, J., Butler, K., Rudolph, J., Glowatz, M., Malkawi, B., Burton, R., Magni, P ve Lam, S. (2020). COVID-19: 20 countries' higher education intra-period digital pedagogy responses. Journal of Applied Learning and Teaching, $3(1), 1-20$.

Datahaus, K. (2020). Slow internet? How COVID-19 is stressing internet infrastructure in your country. Retrieved May 25, 2020 from https://medium.com/@kasprdata/slow-internet-how-covid-19-is-stressing-internet-infrastructure-inyour-country-f94ee6e3b156

Deal, S. B., \& Alseidi, A. A. (2017). Concerns of quality and safety in public domain surgical education videos: an assessment of the critical view of safety in frequently used laparoscopic cholecystectomy videos. Journal of the American College of Surgeons, 225(6), 725-730.

Gong, R. (2020). Coping with Covid-19: Distance Learning and the Digital Divide. KRI VIEWS, 21(20), 1-4

Gralinski, L. E., \& Menachery, V. D. (2020). Return of the Coronavirus: 2019-nCoV. Viruses, 12(2), 135.

Guo, B., \& Li, H. (2020). Guidance strategies for online teaching during the COVID-19 epidemic: a case study of the teaching practice of Xinhui Shangya school in Guangdong, China. Sci Insigt Edu Front, 5(2), 547-551.

Haddouche, H. ve Salomone, C. (2018). Generation Z and the tourist stories and use of social networks. Journal of Tourism Futures, 4(1), 69-79.

Holshue, M. L., DeBolt, C., Lindquist, S., Lofy, K. H., Wiesman, J......., \& Pillai, S. K. (2020). First case of 2019 novel coronavirus in the United States. New England Journal of Medicine, 382(10), 929-936.

Houlden, S., \& Veletsianos, G. (2020). Coronavirus pushes universities to switch to online classes-but are they ready. The Conversation. Retrieved May 28, 2020 from https://theconversation.com/coronaviruspushes-universities-toswitch-to-online-classes-but-arethey-ready-132728

Huang, C., Wang, Y., Li, X., Ren, L., Zhao, J......., \& Cao, B. (2020). Clinical features of patients infected with 2019 novel coronavirus in Wuhan, China. The Lancet, 395 (10223), 497-506. 
Issa, N. (2020). CPS to buy new computers for students to use at home, ramp up e-Learning during Coronavirus shutdown." Chicago Sun-Times. $\quad$ Retrieved May 28,2020 from https://chicago.suntimes.com/coronavirus/2020/3/25/21194851/cps-computers-digital-divide-publicschools-coronavirus-shutdown

Jayakumar, N., Brunckhorst, O., Dasgupta, P., Khan, M. S., \& Ahmed, K. (2015). e-Learning in surgical education: a systematic review. Journal of Surgical Education, 72(6), 1145-1157.

Jones, V., Jo, J., \& Martin, P. (2007, February). Future schools and how technology can be used to support millennial and Generation-Z students. (ICUT 2007), 1st Int. Conf. Ubiquitous Information Technology, (pp. 886-891), Proceeding Books.

Jose Sa, M. \& Serpa, S. (2020). The global crisis brought about by SARS-CoV-2 and its impacts on education: An overview of the Portuguese panorama. Sci Insigt Edu Front, 5(2), 525-530.

Kuckartz, U., \& Radiker, S. (2019). Analyzing qualitative data with MAXQDA. New York: Springer International Publishing.

Kumar, G. S., Angel, T. S. S., Gangwar, A., \& Saksena, K. P. M. (2019). Recommendation system for E-learning platforms, International Journal of Innovative Technology and Exploring Engineering, 8(8), 1956-1960.

Lam, T. T. Y., Shum, M. H. H., Zhu, H. C., Tong, Y. G., Ni, X. B., Liao, Y. S., Wei, W., Cheung, W. Y-M., Li, W-J., Li, L-F., Leung, G. M., Holmes, E. C., Hu, Y-L. \& Guan, Y. (2020). Identification of 2019-nCoV related coronaviruses in Malayan pangolins in southern China. Nature, https://doi.org/10.1101/2020.02.13.945485.

Li, C. M. (2019). How does e-book bag pro-mote learning? Video analysis based on classroom recordings. Sci Insigt Edu Front, 3(1), 135-154.

Lin, W., Chen, Y., Shi, S., Liang, J., Huang, H., Li, L., Cai, L., Zong, L., Wang, N., Wen, J., \& Chen, G. (2020). Thoughts on Higher Medical Education Under Major Public Health Emergencies: Thinking Ahead After COVID-19 Outbreak. medRxiv, https://doi.org/10.1101/2020.04.06.20053918.

MCMC (Malaysian Communications and Multimedia Commission). (2020). 322019 Communications and Multimedia Facts \& Figures. Malaysian Communications and Multimedia Commission. Retrieved June 01, 2020 from https://www.mcmc.gov.my/skmmgovmy/media/General/pdf/3Q_CM_2019.pdf.

Menachery, V. D., Dinnon, K. H., Yount, B. L., McAnarney, E. T., Gralinski, L. E., Hale, A., Graham, R. L., Scobey, T., Anthony, S. J., Wang, L., Graham, B., Randell, S. H., Lipkin, W. I., \& Baric, R. S. (2020). Trypsin Treatment Unlocks Barrier for Zoonotic Bat Coronavirus Infection. Journal of Virology, 94(5), 1-15.

Mirzakhani, M., Ashrafzadeh, H., \& Ashrafzadeh, A. (2010, October). The virtual university: Advantages and disadvantages. (October 2010), 4th International Conference on Distance Learning and Education (pp. 32-36). IEEE, Proceeding Books.

Munster, V. J., Koopmans, M., van Doremalen, N., van Riel, D., \& de Wit, E. (2020). A novel coronavirus emerging in China-key questions for impact assessment. New England Journal of Medicine, 382(8), 692-694.

Patton, M. Q. (2002). Qualitative interviewing. Qualitative research and evaluation methods, 3(1), 344-347.

Paules, C. I., Marston, H. D., \& Fauci, A. S. (2020). Coronavirus infections-more than just the common cold. Journal of the American Medical Association, 323(8), 707-708.

Perlman, S. (2020). Another decade, another coronavirus. The New England Journal of Medicine, 38(8), 760-762

Rodriguez, H. A., Young, M. T., Jackson, H. T., Oelschlager, B. K., \& Wright, A. S. (2018). Viewer discretion advised: is YouTube a friend or foe in surgical education?. Surgical Endoscopy, 32(4), 1724-1728.

Sadeghi, M. (2019). A shift from classroom to distance learning: Advantages and limitations. International Journal of Research in English Education, 4(1), 80-88.

Semenikhina, O. V., Drushlyak, M. G., Bondarenko, Y. A., Kondratiuk, S. M. \& Ionova, I. M. (2019). Open educational resources as a trend of modern education. 42nd International Convention on Information and Communication Technology, Electronics and Microelectronics (MIPRO 2019), (pp. 899-902), Proceeding Books.

Skinner, H., Sarpong, D., \& White, G. (2018). Meeting the needs of the Millennials and Generation Z: gamification in tourism through geocoaching. Journal of Tourism Futures, 4(1), 93-104.

Turner, A. (2015). Generation Z: Technology and social interest. The Journal of Individual Psychology, 71(2), 103-113.

Wang, C., Horby, P. W., Hayden, F. G., \& Gao, G. F. (2020). A novel Coronavirus outbreak of global health concern. The Lancet, 395(10223), 470-473.

Wang, D., Li, X. R., \& Li, Y. (2013). China's "smart tourism destination" initiative: A taste of the service-dominant logic. Journal of Destination Marketing \& Management, 2(2), 59-61

WHO (World Healt Organisation) (2020). Coronvirus (COVID-19). Retrieved June 01, 2020 from https://covid19.who.int/

Wong, M. C., Cregeen, S. J. J., Ajami, N. J., \& Petrosino, J. F. (2020). Evidence of recombination in coronaviruses implicating pangolin origins of nCoV-2019. bioRxiv, https://doi.org/10.1101/2020.02.07.939207.

Yağar, F. ve Dökme, S. (2018). Niteliksel Araştırmaların Planlanması: Araştırma Soruları, Örneklem Seçimi, Geçerlik ve Güvenirlik. Gaz̨i Sağllk Bilimleri Dergisi, 3(3), 1-9.

Yao, J., Rao, J., Jiang, T., \& Xiong, C. (2020). What Role Should Teachers Play in Online Teaching during the COVID-19 Pandemic? Evidence from China. Sci Insigt Edu Front, 5(2), 517-524.

YÖK (Yüksek Öğretim Kurumu). (2020). Retrieved June 01, 2020 from https://www.yok.gov.tr/Sayfalar/Haberler/2020/universitelerde-uygulanacak-uzaktan-egitime-iliskinaciklama.aspx 
Yu, S. (2018). The future role of artificial teachers. Open Edu Res, 34(1),16-28.

Zayapragassarazan, Z. (2020). COVID-19: Strategies for online engagement of remote learners. F1000Research, 9 (246), 1-11.

Zhaohui, W. (2020). How a top Chinese university is responding to Coronavirus. Retrieved June 01, 2020 from https://www.weforum.org/agenda/2020/03/coronavirus-china-the-challenges-of-online-learning-foruniversities/

Zhong, R. (2020). The Coronavirus exposes education's digital divide, The New York Times. Retrieved June 01, 2020 from https://www.nytimes.com/2020/03/17/technology/china-schools-coronavirus.html

Zhou, L., Wu, S., Zhou, M., \& Li, F. (2020). 'School's Out, But Class's On', the largest online education in the world today: Taking China's practical exploration during the COVID-19 epidemic prevention and control as an example. Best Evid Chin Edu, 4(2), 501-519.

Zhou, S., Gu, H., \& Yao, J. (2018). From “strict learning” to "smart learning”: an analysis of the key factors affecting students' academic performance: an empirical study based on the academic quality monitoring data of 262245 students in Jiangsu province. Prim Mid Sch Manag, 32(11): 39-42.

\section{GENİ̧ TÜRKÇE ÖZET}

COVID-19 pandemisi nedeniyle dünyanın birçok ülkesinde eğitime ara verilmiş hatta bazılarında ise eğitim durma noktasına gelmiştir. Türkiye'de ise ilk COVID-19 vakası görüldükten sonra eğitim-öğretim ile ilgili çeşitli önlemler alınmıştır. Bu kapsamda T. C. Cumhurbaşkanlığı tarafından kısa süreli önlemler alınmış ardından Türkiye'de bulunun tüm üniversitelerin bağlı olduğu Yüksek Öğretim Kurumu 18.03.2020 tarihinde Türkiye'deki üniversitelerde 2019-2020 akademik y1lı Bahar döneminde uzaktan eğitim faaliyetleri ile eğitim öğretime devam edilmesini kararlaştırmıştır. Ancak bazı kurum, fakülte veya bölümlerin sahip olduğu nitelikler bu sürecin uygulanabilirliğiyle ilgili bazı endişeleri beraberinde getirmektedir. Bu bilgiler 1şığında uygulama ağırlıklı eğitim verilen turizm bölümlerinde uzaktan eğitim modelinin işlevselliğini ortaya koymak amaçlanmaktadır.

Dünya üzerinde pandemi ile ilgili vaka görülen neredeyse bütün ülkeler uzaktan eğitim modeline geçmiştir. Bu süreçteki başarıyı ülkelerin sosyo-ekonomik yapılarının belirleyeceği bir gerçektir. Bu bağlamda uzaktan eğitime geçişte zorluk yaşayan ülkelerden biri olan Portekiz örneğini incelemek faydalı olacaktır. Ülke eğitimdeki tüm olumsuz etkilerinin üstesinden gelmek için çok refleks göstermiştir. Ancak dijital yeterlilikler, kişisel bilgisayarlar ve internete erişim gibi konuların Portekiz'in tüm nüfus için yaygin olmadığından dolayı bazı zorlukların yaşandığını vurgulanmaktadır. Söz konusu bu zorluklar; Portekiz bir bütün olarak eğitime ara vermeye hazır mı? Zorunlu eğitim alan tüm öğrenciler internet erişimi olan bir bilgisayara sahip mi? Ebeveynler çocuklarını desteklemeye, öğrenmeye ve öğrenmelerini izlemeye teşvik etmeye hazır mi? Okullara yeterli ve güvenli e-öğrenme platformları ve araçları sağlamak için gerekli yatırım yapıldı mı? Son yıllarda, bu profesyonellerin sadece teknolojik yeterlilikler açısından değil, aynı zamanda öğretme-öğrenme stratejileri açısından da e-öğrenme yöntemini öğretmelerini sağlayan doğru bir öğretmen eğitim planı var mı? Ebeveynler, bordrolarını kesmeden, hatta işlerini riske atmadan çocuklarına destek olmak ve yardım etmek için evde kalabilirler mi? gibi cevaplanması gereken soruları beraberinde getirmektedir. Bütün bu sorular Portekiz'de COVID-19 nedeniyle zorunlu olarak geçilen uzaktan eğitimin işlevselliğiyle ilgili endişeleri ortaya koymaktadır (Jose Sa ve Serpa, 2020, s. 527). Bu araştırmanın soruları da bu çalışmadaki sorularla paralellik göstermektedir. Bu kapsamda geliştirilen araştırma soruları aşağıdaki gibidir;

- Türkiye'de COVID-19 sonrasında yükseköğretimde uygulanan uzaktan eğitim modelinin uygulama ağırlıklı turizm eğitimi açısından sahip olduğu güçlü ve zayıf yönleri nelerdir?

- Türkiye'de COVID-19 sonrasında yükseköğretimde uygulanan uzaktan eğitim modelinin uygulama ağırlıklı turizm eğitimine yönelik fırsat ve tehditleri nelerdir?

Araştırmada nitel araştırma yöntemi kullanılmıştır. Veriler mülakat (görüşme) yardımıyla toplanmıştır. Görüşmelerde yapılandırılmamış bir süreç işletilmiş olup, görüşmelerin büyük bir çoğunluğu telekonferans yöntemiyle gerçekleştirilmiştir. Araştırmaya neden teşkil eden COVID-19 salgını ve bundan dolayı getirilen seyahat kısıtlamaları görüşmelerin fiziki olarak gerçekleştirilmesine imkân tanımamıştır. Sadece araştırmacılarla aynı kurumda olan öğretim elemanlarıyla fiziki görüşmeler gerçekleştirilebilmiştir.

Nicel araştırmalarda formülasyon sayesinde tartışması sonlandırılan örneklem büyüklüğü, nitel araştırmalarda tartışılmaya devam etmektedir. Nitel araştırmaların örneklemi konusunda, herhangi bir farklı veri elde edilmeyene kadar devam edilmesi gerekliliğini ifade eden satürasyon (doygunluk) (Yağar ve Dökme, 2018: 4) terimi öne çıkmaktadır. Bu araştırmada da satürasyon göz önünde bulundurulmuş olup, 
araştırma örneklemi 39 kişide sınırlandırılmıştır. Ayrıca örneklem oluşturmada, maksimum çeşitleme yöntemi uygulanmıştır. Maksimum çeşitleme örneklemesiyle çeşitlilik gösterebilecek durumlar arasında ortak paydaların ve farklılık boyutlarının ortaya koyulması amaçlanmaktadır (Baltacı, 2018: 249). Bu amaç doğrultusunda görüşme gerçekleştirilen öğretim üyelerinin, Türkiye ölçeğinde olabildiğince farklı üniversitelere dağılım göstermesine ve unvanlarının da her kademeye dağglım göstermesine özen gösterilmiştir. Katılımcılara ilişkin bilgiler Tablo 1'de yer almaktadır.

Araştırma konusuyla ilgili farklı şekillerde bildirilen görüşlerin yazılı hale dönüştürülmesi ve bir araya getirilmesiyle toplam 52 sayfalık ham veri elde edilmiştir. Toplanan ham veriler bilgisayar destekli olarak içerik analizine tabi tutulmuştur. Analizlerde MAXQDA programı kullanılmışır. MAXQDA haritaları, fikirleri netleştirmek ve kategoriler ile özellikler arasındaki varsayımsal ilişkileri anlamak için kullanılan bir analiz programıdır (Azzopardi ve Nash, 2016, s. 254). MAXQDA aracilığılla içerik analizi amaçlı tematik kodlama gerçekleştirilmiştir (Kuckartz ve Radiker, 2019, s. 10). Belirlenen temalar; güçlü yanlar, zayıf yanlar, fırsatlar ve tehditler şeklinde olup, temaların altında ise öğrenci, personel (teknik ve akademik), eğitim (teorik ve uygulama), altyapı (internet erişimi, bilgilendirme vb.) ve üniversite (organizasyon yapısı, organizasyon iletişimi) kodları yer almaktadır.

Uygulanan modeli Türkiye'nin eğitim sistemi için bazı firsatları da beraberinde getirdiği vurgulanmıştır. Bu firsatlardan en önemlisi ilgili modelin gelecekte olabilecek benzer krizler için gerekli altyapı ve bilgileri kazandırmasıdır. Dünyada uluslararası ilişkilerin fiziksel savaş ve terör ekseninden uzaklaşarak biyolojik savaş eksenine kaydığı bir ortamda salgın gibi krizlerin tekrar gündeme gelmesi olasıdır. Çünkü milenyumla birlikte 3’ü koronavirüsü tipi olmak üzere azımsanmayacak sayıda salgınlar yaşanmıştır. Bunun yanında teknoloji her geçen gün daha geniş alanlara yayılmakta ve buralarda kullanılmaktadır. Eğitim bu alanların başında gelmektedir. Bu yönüyle bu eğitim modelinin ileride yaygınlaşması beklenen online eğitimler için ön deneyim sunması bakımından önemli firsatlar içerdiği söylenebilir. Ayrıca özellikle akademik personel için zaman tasarrufu sağlama ve esnek çalışma sistemi noktasında da birtakım firsatlar içerdiği söylenebilir.

Turizm akademisyenlerinin görüşlerine göre salgin sonrası uygulanan uzaktan eğitim modelinin turizm eğitimi açısından bazı önemli kabul edilecek zayıf yönleri mevcuttur. Öncellikle bu modelde turizm eğitimi ile ilgili yapılması gereken uygulamalı dersler yapılmamaktadır. Hatta dönemlik stajlarını yapan öğrenciler stajlarını bile tamamlayamamıştır. Ayrıca altyapı eksikliği ve internetle ilgili yaşanabilecek erişim problemleri de bu zayıf yönlerden bazılarıdır. Özellikle örgün eğitim veren kurumların altyapı ile ilgili eksikliklerin olası beklenen bir durumdur. İnternet erişimi konusunda da iki temel problem söz konusudur. Birincisi bütün hayat online yaşanmaya başladığı için aşırı yüklenme interneti yavaşlatabilir. İkincisi eğitime verilen arda kırsal bölgelerde yaşayan ailelerinin yanına giden öğrencileri internet temini ve erişimi konusunda sorun yaşayabilirler. Ayrıca interaktifliği engelleyen asenkron uygulamalar ve ölçme ve değerlendirmede yaşanan problemler bu modelin diğer zayıf yönleri olarak ön plana çıkmıştır.

Bu eğitim modelinin turizm eğitimi açısından taşıdığı en büyük risk ise sosyal ilişkiler bağlamındadır. Sosyal bir olgu olan turizmde çalışanların sosyal ilişkilerinin güçlü olması gerekmektedir. Bu eğitim modelinin ögrencilerinin sosyal ilişkilerini olumsuz etkilediği söylenebilir. Ayrıca turizm gibi bölümlerde uygulamalı eğitiminin yapılmaması bu modelin ilgili bölümlerdeki eğitim kalitesini azaltma riski taşımasına neden olmaktadır. Ayrıca özellikle Türkiye'de üniversitelerden veya toplumun sosyal dinamiklerinden kaynaklı olarak öğrencilerin arasında bulunan firsat eşitsizliğinin derinleşme tehlikesi söz konusudur. Nitekim farklı öğrenme ihtiyacı ve koşullarına sahip öğrencilere benzer eğitim modelleri veya derslerin verilmesinin uygun olmadığını ifade edilebilir. Ayrıca modelin uygulanması esnasında etik dışı davranışların yaşanma tehlikesinin de olduğu söylenebilir. 